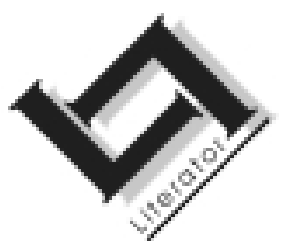

\title{
Tekslinguistiek: van teorie tot praktyk
}

\author{
Susan Prinsloo \\ Departement Afrikaans \\ Universiteit van die Noorde \\ POLOKWANE \\ E-pos: prinsloos@unorth.ac.za
}

\section{Abstract \\ Text linguistics: From theory to practice}

In this article it is argued that theory and practice are reconcilable in the case of text linguistics and the teaching of writing skills. First, text linguistics as a theoretical discipline is explained. Text linguistics, according to De Beaugrande and Dressler (1981), focuses on the seven constitutive principles, as well as the three regulative principles of textuality that determine the linguistic quality or standard of a text. The constitutive principles are cohesion, which in its turn, can be obtained by means of reference, ellipsis, substitution, conjunction and lexical cohesion, coherence, intentionality, acceptability, information, contextuality and intertextuality. The three regulative principles are efficiency, effectiveness and appropriateness. This is followed by a discussion of the relationship between text linguistics and the teaching of writing skills. Knowledge of the principles of text linguistics enables the teacher of writing skills to evaluate texts and to make learners aware of the properties of a "good" text, resulting in effective communication. Text-linguistic concepts are then applied to texts created by Afrikaans second-language speakers. It is then indicated how knowledge of text-linguistic concepts can be an aid in the teaching of writing skills.

\section{Inleiding}

In hierdie artikel word geredeneer dat kennis van die tekslinguistiek, wat in wese 'n teksanalitiese model is, ook aangewend kan word by die onderrig van skryfvaardighede, in die besonder akademiese skryfvaardighede. Die beginsels waaraan 'n suksesvolle teks gemeet word, kan ook by die skep van 'n teks reeds as belangrike rigsnoer dien. 
Du Plessis (2000:133-134) sê dat taal in wese 'n kommunikasiemiddel is en dat die teks die gebruiksmiddel is waarmee gekommunikeer word. Carstens (1997:104) wys byvoorbeeld op die volgende:

Kommunikasie met behulp van taaltekste is nie noodwendig 'n gewaarborgde aktiwiteit nie. Dit is naamlik nodig dat die verwagtinge ten opsigte van 'n teks as 'n sinvolle kommunikasiemiddel nagekom moet word en dat die beginsels van tekstuele kommunikasie in hierdie proses gehoorsaam moet word.

Sekere verwagtinge word ten opsigte van "sinvolle kommunikasie" gestel en indien hieraan voldoen word, sal die teks slaag in sy beoogde doel. Du Plessis (2000:133) stel ook dat die wetenskap in die moderne wêreld nuwe eise stel aan die beoefenaar en leermeester daarvan. In hierdie artikel word vanuit 'n minder tradisionele oogpunt gekyk na die onderrig van Afrikaans as tweede taal (voortaan T2) met die oog op die verbetering van die kommunikatiewe kwaliteit van tekste wat deur hierdie sprekers geskep is. Daar sal gepoog word om aan te toon dat teoretiese kennis aangaande die tekslinguistiek met vrug in die praktyk aangewend kan word in tweedetaalonderrig. Die volgende aspekte sal aandag geniet:

- Die terrein van die tekslinguistiek sal kortliks toegelig word.

- Die verband tussen tekslinguistiek en die onderrig van skryfvaardighede sal onder die loep geneem word.

- Aandag sal geskenk word aan teksanalise vanuit 'n tekslinguistiese oogpunt.

- Laastens sal gelet word op die nut wat die toepassing van tekslinguistiese beginsels vir T2-onderrig inhou.

Wessels (1994:123) sê byvoorbeeld:

Any teacher or lecturer who has marked student essays, whether English compositions or essay-type assignment answers in any given subject, would agree that, especially in the case of ESOL students, one often finds grammatical errors in the essays ...

Dieselfde geld ook waar die studente T2-sprekers van Afrikaans is. Ten einde te kan bepaal in watter mate kennis aangaande die tekslinguistiek kan meehelp in die onderrig van skryfvaardighede, is tekste ontleed wat geskep is deur studente wat T2-sprekers van Afrikaans is en meestal Noord-Sotho as moedertaal het. In enkele gevalle was die moedertaal Xitsonga of Tshivenda. Die studente moes 'n opstel skryf oor een van die volgende onderwerpe waarvan 'n ongeredigeerde voorbeeld van elk hierby ingesluit is: 
- Vertel hoedat jy die afgelope vakansie deurgebring het (Bylaag 1).

- Waarom het jy by die Universiteit van die Noorde kom studeer? (Bylaag 2).

- Vertel van 'n baie aangename of onaangename gebeurtenis wat jy beleef het (Bylaag 3).

Sowel lesergerigte as teksgerigte modelle (vergelyk in hierdie verband Van Tonder, 2000:135) is in die analise gebruik, alhoewel daar meer gekonsentreer is op die teksgerigte benadering, aangesien dit hier gaan om T2-onderrig met die oog op die verbetering van die leerders se kommunikatiewe vaardighede. Daar is gekyk na die sienings teks-asproduk en teks-as-proses. Volgens die teks-as-produk-siening word 'n teks gesien as "... a written product, the coherence of which is determined by textual features" (Wessels, 1994:125). Ten einde te bepaal of die teks koherent is, word gefokus op teksinterne elemente, byvoorbeeld die rol van koherensie. Volgens die teks-as-prosesbenadering word 'n teks gesien as 'n poging deur die teksprodusent om 'n boodskap aan die teksontvanger of teksgebruiker te kommunikeer en die koherensie van die teks hang in 'n groot mate af van die leser se interaksie met die teks. (Vir verdere inligting aangaande genoemde twee modelle, raadpleeg Wessels, 1994.)

\section{Die terrein van die tekslinguistiek}

Volgens Donnelly $(1994: 18)$ is die tekslinguistiek "... devoted to describing how texts are created and understood". Dit werp dus lig op die eienskappe van tekste wat bydra tot hul tekstualiteit.

Uit 'n literatuuroorsig blyk die problematiek rondom die definiëring van die begrip "teks" wat hoofsaaklik ontstaan vanweë die groot aantal tekstipes wat voorkom. Vir die doel van hierdie artikel sal volstaan word met die definisie wat Carstens (1997:82) vir tekslinguistiese studies voorstel, naamlik: "n Teks is 'n stuk taalgebruik wat deur die betrokke deelnemers as EENHEID ervaar en aanvaar word op sintaktiese, semantiese en pragmatiese gronde." Hierdie taaluiting of stuk taalgebruik kan mondeling sowel as skriftelik wees (sien Du Plessis, 2000:139). Carstens (1997:82) sê verder dat dit die taak en doel van die tekslinguistiek is om hierdie eenheid te ondersoek.

'n Teks kan beskou word as geslaagde kommunikasie indien dit 'n samehangende eenheid vorm waar die inhoud op so 'n wyse oorgedra word dat die verlangde reaksie verkry word. 'n Kernbegrip van die tekslinguistiek is "tekstualiteit". Volgens De Beaugrande en Dressler (1981:21) hang die kommunikatiewe sukses van 'n teks af van die 
nakoming van sekere bepalende teksbeginsels wat ingedeel word onder konstitutiewe en regulerende beginsels.

\subsection{Beginsels van tekstualiteit}

\subsubsection{Konstitutiewe beginsels}

Onder konstitutiewe beginsels word die volgende sewe beginsels van tekstualiteit onderskei: kohesie, koherensie, intensionaliteit, aanvaarbaarheid, informatiwiteit, kontekstualiteit en intertekstualiteit. Hierdie beginsel bepaal ' $n$ teks se geldigheid al dan nie. Ten opsigte van hierdie beginsels sê Carstens (1997:105): "(H)ulle skep en definieer die vorm van taalgedrag wat as tekstuele kommunikasie (kommunikasie deur middel van 'n teks) bekend staan", dit wil sê hulle lei tot die totstandkoming van 'n teks.

\subsubsection{Kohesie}

Kohesie het te doen met die samehang in 'n teks waardeur die teks as 'n betekenisvolle eenheid ervaar word. Dit ontstaan op grond van "the way certain words or grammatical features of a sentence can connect that sentence to its predecessors and successors in a text" (Hoey, 1991:3). Carstens (2000:6) stel byvoorbeeld die volgende: "Kohesie het breedweg te doen met die wyse waarop die oppervlakskomponente van die sinne wat in tekste voorkom, dit wil sê die onderskeie woorde, onderling verwant ... is." Halliday en Hasan (1976:8) sien kohesie as "a semantic relation between an element in the text and some other element that is crucial to the interpretation of it". Leksiko-grammatiese elemente van die taal word gebruik om semantiese verhoudings sintakties in die oppervlakteteks te vergestalt. Carstens (2000:6) wys op die kardinale rol wat die sintaktiese kennis van 'n taalgebruiker speel by die totstandkoming van sodanige verhoudings. Konjunksiemerkers word byvoorbeeld gebruik om bepaalde verbande tussen gedagtes bloot te lê en 'n gebrekkige sintaktiese kennis kan daartoe aanleiding gee dat konjunksiemerkers verkeerdelik gebruik word en die aangewese verbande nie gelê word nie. Bylaag 2 begin byvoorbeeld met die volgende sin:

Wanneer ek by die Universiteit kom studeer het ek gedink om 'n verpleegster student te wees omdat ek hou baie van gesondheid.

Die konjunksiemerker wanneer word gewoonlik in 'n tydsaanduidende hoedanigheid ten opsigte van toekomstige gebeure in 'n voorwaardelike verband gebruik (sien Carstens, 1997:292). In bostaande voorbeeld word daar egter verwys na 'n gebeurtenis wat reeds plaasgevind het wat dus nie toekomstig "voorwaardelik" kan wees nie. Hierdie foute kan toegeskryf word aan 'n gebrekkige sintaktiese kennis. 'n Verdere 
voorbeeld wat ook toegeskryf kan word aan 'n gebrekkige kennis van die verwysingsisteem van Afrikaans, is die foutiewe gebruik van voornaamwoorde wat dikwels in die tekste van T2-sprekers van Afrikaans voorkom, byvoorbeeld:

Sy vertel sy man van die gebeure.

'n Aantal tekste wat deur T2-sprekers van Afrikaans geskep is en vir die doel van hierdie artikel ontleed is, toon dat dit dikwels juis 'n gebrekkige sintaktiese kennis is wat onsuksesvolle kommunikasie tot gevolg het. (Vergelyk Afdeling 5 vir meer besonderhede aangaande die data wat ontleed is.)

Aangesien die konsep kohesie reeds deeglik in die literatuur verantwoord is (vgl. byvoorbeeld Halliday \& Hasan, 1976 en Carstens, 1997), sal hier slegs kortliks daarop ingegaan word. Aangaande kohesie sê Halliday en Hasan (1976:13) "... the concept of cohesion accounts for the essential semantic relations whereby any passage of speech or writing is enabled to function as text". Daardie elemente in die teks wat die essensiële semantiese verhoudings vorm, dus semanties met mekaar skakel, word 'n kohesieketting genoem. Die funksie van kohesiekettings is om die verhouding tussen sinne of sinsdele in die oppervlakteks aan die lig te bring (vgl. Carstens \& Van Schalkwyk, 1994:46). Die volgende vyf tipes kohesiekettings word onderskei: verwysing, substitusie, ellips, konjunksie en leksikale kohesie.

\subsection{Verwysing}

Verwysing het te make met die beginsel dat twee of meer elemente in dieselfde teks semanties met mekaar geassosieer kan word omdat beide na dieselfde referent (die persoon of ding ter sprake eie toevoeging) in die werklikheid verwys (Carstens, 1987:22).

Een item, die anafoor, is vir korrekte interpretasie aangewese op 'n ander item, die antesedent (Prinsloo, 1994:151). Deur middel van die antesedent word die referent geïdentifiseer en geïndividualiseer (byvoorbeeld 'n selfstandige naamwoord, soos 'n spook - Bylaag 3). Na hierdie referent kan weer (anafories of katafories) verwys word deur middel van 'n leksikale item waarvan die inligtingsinhoud te laag is om die funksie van identifikasie en individualisasie te vervul, naamlik die anafoor, byvoorbeeld 'n voornaamwoord, soos:

... ek skrik my boeglam toe ek hom sien (Bylaag 3, verwysend na die spook). 
Hubbard (1994:77) gee 'n uiteensetting van die belangrike rol wat verwysing speel ten opsigte van die verkryging van 'n koherente teks en haal in hierdie verband Sanford en Garrod aan, naamlik: "(r)eference resolution in all its forms constitutes the cornerstone of successful comprehension in terms of the reader's task of building an appropriate mental model of what is being said".

\subsection{Substitusie}

In die geval van substitusie word een element in 'n teks deur 'n ander vervang. Carstens (1997:220) stel dit soos volg:

Een element in 'n sin word onder sekere grammatikale en kontekstuele omstandighede vervang deur ' $n$ ander (ruil)element wat in die betrokke element se plek kan optree.

Die antesedent en anafoor verwys in hierdie geval nie na dieselfde referent nie, maar na "verskillende eksemplare van dieselfde tipe saak of toestand" (Carstens, 1997:222). Vergelyk byvoorbeeld Bylaag 3: 'n groot hand $\mathrm{x}$ daardie een waar na verskillende eksemplare van dieselfde saak verwys word.

\subsection{Ellips}

Ellips hou verband met die weglating van 'n element en in die plek van die weggelate element ontstaan 'n gaping. Hierdie gaping moet dan ter wille van interpretasie met ' $n$ element elders in die teks geassosieer word. In Bylaag $2 \mathrm{kom}$ die volgende voorbeeld van ellips van die persoonlike voornaamwoord ek asook die hulpwerkwoord wil voor:

Hierdie jare, ek beplan om eendag 'n joernalis te wees, ek wil 'n geleerde persoon met mooi huisie, motor en 'n goeie werk hê en [ek wil] 'n goeie salaris kry om my kinders by die hoër skole toe stuur.

\subsection{Konjunksie}

By konjunksie gaan dit nie om die skakeling van leksikale items met mekaar nie, maar wel om die skakeling van proposisies in verskillende sinne. Skakeling vind plaas deur middel van konjunksiemerkers wat gebruik word om bepaalde semantiese relasies (byvoorbeel teenstellend, temporeel, aaneenskakelend, ensovoorts) uit te druk. In Bylaag 3 word die konjunksiemerker want in die tweede sin gebruik in 'n redegewende verband om oorsaak aan te dui:

Daardie dag het ek 'n spook gesin, want dit was 'n skaduwee soos 'n persoon nie 'n gewoonlike mens nie. 


\subsection{Leksikale kohesie}

By leksikale kohesie gaan dit om semantiese relasies wat tussen verskillende leksikale items in 'n teks ontstaan. 'n Semantiese verwantskap kan byvoorbeeld ontstaan tussen woorde in die geval van sinonieme, antonieme, meronieme, hiponieme en superordinate, kollokasie, ensovoorts. Die volgende woorde (Bylaag 2) kom byvoorbeeld dikwels in dieselfde omgewing voor, dit wil sê dit vorm 'n kollokasie:

universiteit, studeer, student, studie, vak, hoofvak.

Semantiese velde wat rondom die leksikale item "universiteit" bestaan, is hier ter sprake.

Carstens (1997:132) beklemtoon die feit dat kohesie nie gesien moet word as die vernaamste beginsel van tekstualiteit nie. In hierdie verband sê hy:

Tekstualiteit word wel teweeggebring deur die linguistiese struktuur van 'n teks, maar dit word beslis nie daardeur bepaal en beperk nie. ... (K)ohesie is slegs ' $n$ middel tot 'n doel (die skep van 'n kommunikatiewe teks) en nie die doel op sigself nie.

Kohesie lewer egter 'n belangrike bydrae tot die duidelik volgbare struktuur van 'n teks en bevorder sodoende effektiewe kommunikasie.

\subsubsection{Koherensie}

Koherensie word gesien as die mees sentrale begrip in die tekslinguistiek (sien Van Schalkwyk \& Carstens, 2000:109, asook Hubbard, 1993:55, 57). Koherensie het te doen met dit wat bydra dat 'n teks vir taalgebruikers sin maak, asook "... the way in which information "hangs together' or coheres in texts" (Pretorius, 1994:84). Dit gaan dus in hierdie opsig om 'n semantiese eenheid en hou verband met die "verstaan" van 'n teks. Onderlinge begrippe in die teks moet met mekaar verband hou. Bylaag 1 is 'n voorbeeld van 'n teks wat 'n gebrek aan koherensie toon. Die derde paragraaf begin byvoorbeeld met die sin:

Waar het ek gekry.

Hierdie sin hou geen verband met die voorafgaande of daaropvolgende teksgedeeltes nie en dit versteur die semantiese eenheid van hierdie teks. Carstens (2000:7) sê dat as 'n teks nie verstaan word nie, is 'n "goeie teks" nie geproduseer nie. Volgens Bamberg (1984:305) is koherensie essensieel "if writing is to communicate its intended meaning to a reader, and teaching students to write coherently has been and 
continues to be an important aspect of writing instruction". In die navorsing wat vir hierdie artikel gedoen is, is gepoog om vas te stel waarom een teks meer aanvaarbaar is as 'n ander deur verskillende tekste te analiseer aan die hand van die standaarde wat gestel word vir tekstualiteit (vergelyk die voorafgaande Afdeling 2). In hierdie verband kan Neubert en Shreve se siening, soos aangehaal deur Carstens (2000:7), as gids dien: "A coherent text has an underlying logical structure that acts to guide the reader through the text", sodat 'n sinvolle eenheid gevorm word.

\subsubsection{Intensionaliteit}

Die klem val hier op die teksproduseerder en sy bedoeling met die teks. Die produseerder wil eerstens 'n kohesiewe, koherente teks tot stand bring, maar by die totstandkoming van ' $n$ teks is ook ander besondere intensies betrokke wat deur die teksstruktuur na vore gebring moet word (vgl. in hierdie verband De Beaugrande \& Dressler, 1981:113-126, asook Carstens, 1997:370-379.)

\subsubsection{Aanvaarbaarheid}

Aanvaarbaarheid hou verband met die voorafgaande beginsel, naamlik intensionaliteit, aangesien albei te doene het met die deelnemers aan die teksgebeurtenis, dit wil sê die teksproduseerder sowel as die teksontvanger of teksgebruiker. Carstens (1993:8) stel dat sowel intensionaliteit as aanvaarbaarheid te doene het met "... die bydraes wat die deelnemers aan 'n teksgebeurtenis moet lewer om die teks as 'n taalhandeling te laat slaag". Die teksontvanger of -gebruiker se houding teenoor die teks is hier van belang. Laasgenoemde moet aanvaar dat die teks bedoel is as ' $n$ kommunikatiewe teks en dui ook, in De Beaugrande en Dressler (1981:129) se woorde, op "... active willingness to participate in a discourse". Die sogenaamde "samewerkingsbeginsel" wat deel vorm van die "gespreksbeginsels" wat deur Grice, soos aangehaal deur Carstens (1997:363-364) opgestel is, is hier ter sprake. Dit hou in dat sowel die teksproduseerder as die teksontvanger of -gebruiker moet saamwerk om van die kommunikasiegeleentheid 'n sukses te maak. Die teksontvanger of -gebruiker moet van sy kant af 'n gewilligheid toon om deel te neem aan die kommunikasieproses (sien in hierdie verband Carstens, 1997:379-384).

\subsubsection{Informatiwiteit}

Die vyfde beginsel is dié van informatiwiteit waar gefokus word op die aard en wyse waarop inligting met behulp van die teks oorgedra word sodat belangriker inligting van minder belangrike inligting onderskei 
word. Carstens (1997:435) se standpunt is dat dit te doen het met die wyse waarop die bedoeling en inhoud van 'n sekere taalteks oorgedra word. Aangesien sekere inligting in 'n teks van groter kommunikatiewe belang is as ander inligting in daardie teks, sal die aanbieding van die inligting verskil. Nuwe inligting in ' $n$ teks is byvoorbeeld belangrik ten einde die hoorder se belangstelling in 'n teks te behou en dit is van groter kommunikatiewe waarde. Die teksproduseerder poog om die inligting wat hy wil oordra, dit wil sê die boodskap, op so 'n wyse te organiseer dat die kommunikatiewe oordrag inderdaad sal slaag.

\subsubsection{Kontekstualiteit}

Taal kan nie losgemaak word van die konteks waarin dit gebruik word nie. 'n Teks hou verband met die omstandighede waarin die tekshandeling plaasvind. Situasionele faktore speel in hierdie opsig 'n belangrike rol, byvoorbeeld die teksdeelnemers en die verhouding tussen hulle. Die kwaliteit en effektiwiteit van kommunikasie word in 'n groot mate bepaal deur gedeelde kennis tussen die teksproduseerder en die teksontvanger of -gebruiker. (Ten opsigte van kontekstualiteit, vergelyk De Beaugrande \& Dressler, 1981:161-181, asook Carstens, 1997:386-425 en Carstens \& Van Schalkwyk, 1994:556.)

\subsubsection{Intertekstualiteit}

Reeds bestaande kennis oor 'n bepaalde teksstruktuur speel hier 'n belangrike rol. Die vorming en interpretasie van een teks kan beïnvloed word deur die kennis van die struktuur van 'n ander soortgelyke teks. Carstens (2000:9) wys daarop dat 'n persoon byvoorbeeld op grond van sy bestaande kennis aangaande nuusberiggewing 'n koerant aanvaar as 'n koerant. Hy (Carstens, 2000:14) sê voorts dat intertekstualiteit verband hou met "... kennis van tekstipes, kennis van die eise wat aan besondere tekste gestel word, kennis van die wyse waarop een teks 'n ander kan beïnvloed".

\subsubsection{Regulerende beginsels}

De Beaugrande en Dressler (1981:21) definieer die regulerende beginsels, doeltreffendheid, effektiwiteit en geskiktheid, as kriteria "which distinguish the quality of a sample already admitted as a text".

\subsubsection{Doeltreffendheid}

Carstens (1997:106) som hierdie beginsel soos volg op: "Die doeltreffendheid (efficiency) van 'n teks word bepaal deur die mate van inspanning wat aan die kant van die teksdeelnemers vereis word om die teks te laat slaag as kommunikatiewe handeling", dit wil sê hoe maklik of 
moeilik 'n teks geproduseer of geïnterpreteer word. Hubbard (1989:104) wys daarop dat alhoewel dit by De Beaugrande en Dressler (1981) hoofsaaklik gaan om die inspanning wat van die leser geverg word om die teks te interpreteer, hierdie beginsel daarop gerig is "to accommodate the perspective of both writer and reader".

In die geval van T2-onderrig sal die onderwyser of dosent met sy hoër vlak van taalkennis daarop bedag moet wees dat die teksproduseerders ' $n$ teks daarstel wat verstaanbaar is en vloeiend lees sodat die lees daarvan nie soveel inspanning van die leser verg dat hy belangstelling daarin sal verloor nie. Die gebruik van foutiewe voornaamwoorde of konjunksiemerkers kan byvoorbeeld aan die teksprodusente uitgewys word en deur die verbetering hiervan kan 'n teks se leesbaarheid vergemaklik word (vergelyk Afdeling 5).

\subsubsection{Effektiwiteit}

Die effektiwiteit van 'n teks hang volgens De Beaugrande en Dressler (1981:11) daarvan af of dit 'n goeie indruk laat en of gunstige omstandighede geskep is ten einde ' $n$ bepaalde doel te bereik. In 'n poging om in hierdie doel te slaag, kan by die skep van 'n teks van woordeboeke gebruik gemaak word en woorde waarvan die betekenis nie aan die teksgebruikers bekend is nie, kan in die teks gebruik word. Hierdeur kan die leesproses sodanig bemoeilik word dat dit daartoe aanleiding gee dat die kommunikasieproses nie slaag nie.

\subsubsection{Geskiktheid}

Die beginsel geskiktheid hou verband met die gepastheid van 'n sekere teks in 'n bepaalde konteks. Kruger (2000:111) wys daarop dat “... efficiency tends to work in the direction of easy processing but trite content ... while effectiveness tends to go with powerful content but can lead to text that is unduly difficult to process", terwyl geskiktheid "... must mediate between these opposed factors to indicate the proper balance between the conventional and the unconventional in each situation" (De Beaugrande \& Dressler, 1981:34). By T2-onderrig sal die taalvaardigheidsvlak van die teksproduseerders in ag geneem moet word. Daar moet gewaak word teen die skep van 'n teks wat in so 'n mate vereenvoudig is dat dit vervelig is en geen indruk op teksonvangers sal maak nie. Aan die ander kant moet ook daarteen gewaak word dat woordgebruik van so 'n hoë vlak is dat dit die verstaanbaarheid van die teks bemoeilik, of soos Kruger (2000:110) dit stel: “... the sheer oddity of the language may put a reader off altogether". 


\section{Tekslinguistiek en skryfvaardighede}

By die onderrig van skryfvaardighede aan T2-studente is die hoofdoel om die studente in staat te stel om 'n verstaanbare teks te kan produseer met die oog op geslaagde kommunikasie deur middel van aanvaarbare taalgebruik. Die tekslinguistiek spits hom daarop toe om die tekstualiteit, dit wil sê die aanvaarbaarheid al dan nie van 'n teks te bestudeer deur middel van die genoemde beginsels van tekstualiteit. By die tekslinguistiek gaan dit om "... how texts are created and understood ..." (Donnelly, 1994:18). By sowel die skep as die verstaan van 'n teks gaan dit om die produksie van 'n aanvaarbare teks wat sal lei tot geslaagde kommunikasie.

Carstens (1997:7) sê dat dit by die tekslinguistiek nie net gaan om die vorm en struktuur van die linguistiese teks nie (dit wil sê kohesie) nie, maar dat ander faktore ook 'n rol speel, naamlik die spreker wat die bedoeling het om inligting te kommunikeer, die aangesprokene wat die inligting moet aanvaar, die sosiale konteks waarbinne die kommunikasie plaasvind en die kennis van vroeëre soortgelyke tekste. Al hierdie faktore speel ' $n$ rol ten opsigte van die inhoudelike samehang (koherensie) van 'n teks.

\section{Toepassing van die standaarde van tekstualiteit}

\section{1 Intertekstualiteit}

By intertekstualiteit gaan dit om genrekennis en die persoon wat die skryfvaardighede onderrig, moet kennis dra van hoe die bepaalde teks struktuurgewys behoort te lyk. Die struktuur van 'n brief verskil byvoorbeeld van dié van 'n opstel of 'n gedig. Die bepaalde vorm en struktuur wat 'n verlangde teks moet aanneem, sal dus vooraf aan die leerders verduidelik moet word en die onderwyser of dosent sal moet toesien dat die tekste in ooreenstemming met hierdie struktuurvereistes gegenereer word, aangesien 'n produk wat aan die struktuurverwagtinge van die leser voldoen, bydra tot geslaagde kommunikasie

\subsection{Intensionaliteit en aanvaarbaarheid}

Waar ' $n$ teks geproduseer word, het die produsent ' $n$ bepaalde doel daarmee voor oë. Die produsent wil bepaalde inligting of 'n boodskap oordra en ten einde die kommunikatiewe handeling te laat slaag, moet die aangesprokene 'n aanduiding gee dat hy die aanbod aanvaar, of soos Carstens (2000:12) dit stel: “... hy moet ... gewillig wees om die goeie bedoeling van die teksproduseerder te aanvaar as 'n geldige oordrag van inligting". Die onderwyser of dosent speel hier 'n belangrike 
rol aangesien hy moet toesien dat 'n teks gegenereer word wat die bedoeling van die teksprodusent oordra. Dit wat die effektiewe oordrag van 'n boodskap belemmer, moet uitgewys en gekorrigeer word. Dit is belangrik dat die onderwyser of dosent die intensie van die teksprodusent sal snap en waar T2-sprekers soms in gebreke bly om die boodskap doeltreffend te formuleer, moet die onderwyser of dosent die leerder hiermee behulpsaam wees. Bylaag 1 is 'n voorbeeld waar die teksprodusent nie daarin geslaag het om sy boodskap effektief oor te dra nie as gevolg van oneffektiewe taalgebruik, byvoorbeeld onverstaanbare, onsamehangende sinne, soos, onder andere, die sin aan die einde van die eerste paragraaf, naamlik:

Dit was heerlik swaar vir my om my toekomsplanne te kan voorkom.

asook die tweede sin in Paragraaf 2, naamlik:

Hard soos wat dit was, het ek my planne voorkom.

\subsection{Kontekstualiteit}

Enige stuk taalgebruik ontstaan binne 'n bepaalde konteks en die teksdeelnemers in die bepaalde konteks speel 'n belangrike rol. Daar moet daarmee rekening gehou word dat die teksprodusent 'n T2-spreker is en die onderwyser of dosent moet bedag wees op foutiewe taalgebruik en sinskonstruksies, asook op spelfoute wat kan lei tot die foutiewe oordrag van inligting of die leesproses sodanig kan belemmer dat die leser belangstelling in die teks kan verloor. Binne hierdie gegewe konteks word daar van die onderwyser of dosent verwag om 'n leidende rol te speel ten opsigte van die verbetering van die taalaanbod sowel as die struktuurfoute, deur die leerlinge of studente daarop bedag te maak. Gedeelde agtergrondkennis is van groot belang met die oog op geslaagde kommunikasie. Sekere sosiale faktore speel ook in hierdie opsig 'n belangrike rol. Indien die leerders op skool is, moet die leerstof, byvoorbeeld temas vir opstelle, aanpas by hul ouderdom en ervaringswêreld. Die onderwyser of dosent moet rekening hou met die taalvaardigheidsvlak van die leerder, wat byvoorbeeld vooraf deur middel van toetse wat vir hierdie doel opgestel is, bepaal is, en dan daarby aanpas. Die sosiale agtergrond van die leerder (byvoorbeeld die tipe gemeenskap waaruit die leerder kom) moet ook in aanmerking geneem word en kan 'n belangrike rol speel wanneer dit kom by kennis aangaande bepaalde onderwerpe. In hierdie geval moet nie soseer rekening gehou word met die teksontvanger se situasie nie, maar eerder met dié van die teksprodusent, aangesien dit hier hoofsaaklik gaan om die onderrigsituasie. Die rol van die onderwyser of dosent is om leiding te gee ten opsigte van die verbetering van die taalstruktuur van die teks 
sodat die bedoelde boodskap daardeur oorgedra word en die kommunikasieproses slaag.

\subsection{Informatiwiteit}

Die onderwyser of dosent sal teksgerig te werk moet gaan en aandag moet skenk aan hoe die leerder die teks konstrueer sodat belangrike inligting van minder belangrike inligting onderskei word en dat die teks sodanig gekonstrueer is dat die verskil in die informasie daardeur oorgedra word. In Bylaag 3 begin Paragraaf 3 met 'n beskrywing van die lig wat só helder was dat die gedaante nie behoorlik waargeneem kon word nie. Dit is belangrike inligting wat reeds vroeër in die teks in Paragraaf 2 die tweede sin ingevoeg moes gewees het. By die uitlig van belangrike inligting speel kennis aangaande sekere sintaktiese strategieë wat vir dié doel aangewend kan word, byvoorbeeld plasing, splitsing, beklemtoningsadjunkte, ensovoorts (vgl. Ponelis, 1979:537-559) 'n belangrike rol. Die effek van hierdie strategieë op 'n taalaanbod kan aan die leerders uitgewys word. In Bylaag 3, Paragraaf 1 is in die tweede sin van die normale stelsinvolgorde afgewyk en die sin begin met 'n adjunk van tyd, naamlik daardie dag waardeur klem geplaas word op die tyd toe die nagmerriegebeurtenis plaasgevind het. Nuwe inligting moet op so 'n wyse aangebied word dat dit help om die hoorder se aandag te behou. Die inligting in die teks moet sodanig georden wees dat die inhoud die bedoeling van die produsent weergee. Belangrike of nuwe inligting moet sodanig aangebied word dat dit uitstaan en onmiddellik onder die aandag van die hoorder sal kom.

\subsection{Koherensie}

Van Tonder (2000:136) wys in hierdie verband byvoorbeeld op die volgende: "Part of the study of coherence centres around how texts are organised in terms of the presentation and development of concepts within the context of the task with which the writer is presented." In die geval van die navorsing wat hierdie artikel onderlê, moes die studente opstelle skryf oor bepaalde onderwerpe en dit is te wagte dat die "... choice of lexical cohesion items in the introductory and concluding statements of the essays would be influenced by the question to which the essays were a response". Bylaag 4 is byvoorbeeld 'n respons op die opdrag om 'n opstel te skryf oor 'n baie onaangename gebeurtenis. Die opskrif is "'n Nagmerriegebeurtenis" en hierdie leksikale items word in die openingsin, asook in die slotsin herhaal, waardeur koherensie in die hand gewerk word.

Die onderwyser of dosent sal die nodige leiding aan die studente of leerlinge moet verskaf sodat die leerders 'n verstaanbare teks produseer 
wat ook 'n sinvolle eenheid vorm. Die teksprodusent se bedoelde betekenis moet op 'n logiese wyse deur middel van die teks oorgedra word. Daar sal byvoorbeeld sorg gedra moet word dat daar 'n deurlopende tema in die skryfwerk is en dat paragraafindeling logies en sinvol opeenvolg. Daar sal gewaak moet word teen sinne wat op onlogiese plekke in die teks geplaas word en die tekseenheid versteur. Sinne wat nie verband hou met die inhoud van die paragraaf nie, lei dikwels by die tekste van T2-sprekers daartoe dat lesers belangstelling verloor as gevolg van 'n onlogiese geheel, soos byvoorbeeld in Bylaag 1, die laaste sin van die eeste paragraaf, die tweede sin van die tweede paragraaf en die eerste sin van die derde paragraaf. By die onderrig van skryfvaardighede aan T2-sprekers is dit baie belangrik dat die onderwyser of dosent moet toesien dat die leerders in staat is om ' $n$ sinvolle, samehangende teks daar te stel sodat die teksproduseerder die gewensde inligting deur middel van sy teks sal oordra.

\subsection{Kohesie}

Kohesie lewer 'n belangrik bydrae in die totstandbrenging van 'n koherente teks. Aangesien dit by kohesie gaan om die oppervlakstruktuur van 'n teks, speel taalbeheersing 'n belangrike rol. Semantiese verhoudings word in die teks deur middel van leksiko-grammatiese elemente vergestalt. Die betekeniswaarde wat aan woorde geheg word, die plasing van woorde in sintaktiese verband, die wyse waarop sinne onderling verbind word en die plasing van die sinne in die teksgeheel, hou verband met die skepping van 'n oppervlakstruktuur wat die kwaliteit van die kommunikatiewe oordrag beïnvloed. Kennis van die verskillende kohesiemerkers en hul werking sal vir die onderwyser of dosent van groot waarde wees by skryfonderrig en die beoordeling van die tekste van T2-sprekers. In die taalgebruik van T2-sprekers is dit veral ten opsigte van die kohesiemerkers verwysing en konjunksie waar probleme ontstaan. In Afrikaanse tekste wat deur T2-sprekers geskep is, is voornaamwoordgebruik dikwels foutief as gevolg van 'n gebrekkige kennis van die verwysingsisteem van Afrikaans. As voorbeeld in dié verband geld die gebruik van sy in plaas van haar/hy en konjunksiemerkers, veral dié wat verband hou met tydsvergestalting, wat dikwels foutief gebruik word, byvoorbeeld dan (wat verband hou met 'n tydstip in die toekoms) in plaas van toe (wat verwys na 'n tydstip in die verlede). Kyk byvoorbeeld Bylaag 3 in die tweede en derde sin van Paragraaf 2: "... dan hoor ek ..." en "... dan ek skrik ..." (vergelyk ook Afdeling 5). Hierdie foute bemoeilik die teks se leesbaarheid en lei daartoe dat foutiewe semantiese skakels ontstaan. Kohesie speel 'n belangrike rol om die korrekte semantiese skakels te vorm in die totstandbrenging van effektiewe, geslaagde kommunikasie. 


\subsection{Doeltreffendheid}

Soos uit die ingeslote tekste blyk, veral Bylaag 1 en 2, word effektiewe kommunikasie bemoeilik deurdat dit baie inspanning van die leser verg om die teks te verstaan. 'n Gebrek aan taalvaardigheid is hiervoor verantwoordelik, soos die talle onlogiese sinskonstruksie in Bylaag 1, byvoorbeeld die derde sin van die eerste paragraaf en die eerste sin van die derde en vierde paragraaf. Spelfoute bemoeilik ook die leesbaarheid van die tekste, byvoorbeeld dranks en dagliks in Bylaag 1 en kis in Bylaag 2. 'n Gebrekkige woordeskat soos die gebruik van preparee in Bylaag 1 kan ook in hierdie verband genoem word. Die ondersoekte tekste het dikwels voorbeelde bevat van wat bestempel kan word as "the sheer oddity of the language" (Kruger, 2000:110), byvoorbeeld:

- Bylaag 1: "Alles van koopbar."

- Bylaag 2: "Ek was baie teleurgesteld omdat die gesondheidspasie in die Universiteit van die Noorde was vol ..."

- Bylaag 3: "Ek kon nie praat nie, my stem was loos."

Ondoeltreffende taalgebruik in die ondersoekte tekste bemoeilik die leesproses en gee daartoe aanleiding dat Afrikaanssprekendes belangstelling in hierdie tekste verloor en dit lei dus tot onsuksesvolle kommunikasie.

\subsection{Effektiwiteit}

Soos uit die voorafgaande bespreking blyk, laat die ondersoekte tekste dikwels nie 'n goeie indruk nie as gevolg van genoemde redes. Dit lei daartoe dat die kommunikasieproses onsuksesvol is.

\subsection{Geskiktheid}

In hierdie verband speel die onderwyser of dosent in T2-onderrig 'n belangrike rol om te verseker dat daar 'n balans is tussen doeltreffendheid en effektiwiteit. Die onderwerpe waaroor teksprodusente moet skryf en hul taalvaardigheidsvlak moet geskik wees vir bepaalde teksproduseerders. Daar moet dus 'n balans wees tussen die vermoëns van die teksproduseerders en die geproduseerde tekste.

Deur die standaarde van tekstualiteit nie net by die beoordeling van 'n teks nie, maar veral ook by die totstandkoming van 'n teks in gedagte te hou, kan verseker word dat 'n teks wat sal lei tot effektiewe kommunikasie, geskep word. Kennis van die beginsels van tekstualiteit verskaf nie net aan die onderwyser of dosent 'n raamwerk van vereistes waaraan 'n effektiewe teks moet voldoen nie, maar is ook ' $n$ hulpmiddel by die bepaling en uitwys van gebreke by die onsuksesvolle teks. 


\section{Teksanalise}

Die tekste wat ontleed is (vergelyk Afdeling 1), is geproduseer deur Afrikaans-T2-sprekers wat Afrikaans as hoofvak vir graaddoeleindes aan die Universiteit van die Noorde neem.

Daar is reeds genoegsaam aandag geskenk aan die regulerende beginsels in die voorafgaande gedeelte en in hierdie afdeling sal slegs gelet word op aspekte wat verband hou met die konstitutiewe beginsels.

Daar is reeds in Afdeling 2.1.1 gewys op die belangrikheid wat kennis aangaande die sisteem van ' $\mathrm{n}$ taal inhou vir die teksproduseerder. Kohesie het juis te doen met "die wyse waarop woorde volgens die struktuurpatrone van 'n besondere taal gekombineer word om effektiewe sinne te vorm, wat weer tot die oordrag van effektiewe kommunikasie kan lei" (Carstens, 2000:11), dit wil sê kommunikasie waardeur die beoogde inligting wel oorgedra word. In die ondersoekte tekste het gebrekkige sinsformulering veral opgeval, soos in Bylaag 1 en 2. Verder kom foutiewe betekenisskakels ook dikwels voor waardeur die teks inboet aan tekstuele kontinuïteit en verstaanbaarheid (vergelyk Bylaag 1, Paragraaf 1).

Verwysing vind plaas waar twee of meer naamwoordelike elemente met mekaar geassosieer word en albei na dieselfde referent verwys. In die tekste is gevind dat die antesedent wat die nuwe inligting bevat meestal eerste genoem word en daarna die anafore, dit wil sê vooruitwerkende anaforiek het meestal voorgekom. In Bylaag $3 \mathrm{kom}$ die antesedent 'n spook in die tweede sin voor, gevolg deur die anafore iets in die derde sin, die skaduwee en hom in die tweede paragraaf en hom, sy, hy, hy, en sy in die derde paragraaf, asook hom in die vierde paragraaf. Hierdie antesedent en anafore verwys almal na dieselfde referent.

As gevolg van gebrekkige taalkennis moes die leser soms op grond van eie taalkennis afleidings maak oor die antesedentnaamwoordstukke, byvoorbeeld:

Bed kamer in plaas van slaapkamer

Stadaanklaer in plaas van staatsaanklaer

Dit bring aanvanklike verwarring mee en bemoeilik die leesproses. Persoonlike voornaamwoorde van die derde persoon word meestal as anafore gebruik en daar is gevind dat voornaamwoorde dikwels nie ten opsigte van geslag en getal ooreenstem met die antesedent nie, byvoorbeeld haar in plaas van sy waar verwys word na 'n manlike referent of $s y$ in plaas van haar in geval van vroulike referente. Saam 
met die lidwoord ' $n$ word dikwels meervoudsvorme gebruik, byvoorbeeld 'n soorte dinge, ook vorme soos elke dinge.

Die beginsel waarvolgens daar vir die eerste maal in 'n teks deur middel van die onbepaalde lidwoord as bepaler (determineerder) binne die naamwoordstuk (voortaan NS) na 'n nuwe referent verwys word en daarna deur middel van die bepaalde lidwoord die as determineerder binne of van die NS, word meestal oorboord gegooi, byvoorbeeld:

Ek glo nie aan spoke nie maar daardie nag ek glo dat die spook was daar.

Die onbepaalde lidwoord ' $n$ word dikwels verkeerdelik saam met nietelbare selfstandige naamwoorde gebruik, byvoorbeeld:

Hulle moet 'n tronkstraf kry.

Epiteta is in enkele gevalle gebruik. Ten opsigte van epiteta sê Carstens (1997:175): “... hulle [dien] as etikette, dit wil sê as waarnemings of oordele oor die referent gesien vanuit 'n bepaalde hoek (positief of negatief)". (Vir 'n verdere uiteensetting van epiteta sien Prinsloo \& Seshoka, 2000:98-99.) Die gebruik van epiteta (byvoorbeeld snuitertjie), asook afwisselende leksikale naamwoordstukke (byvoorbeeld spook, iets bonatuurliks, wit gedaante, gees) was beperk en het in talle tekste ontbreek. Dit kan waarskynlik toegeskryf word aan 'n gebrekkige woordeskat.

Die kohesiekettings substitusie en ellips lewer 'n uiters beperkte bydrae in die ondersoekte tekste. Ellips kom byvoorbeeld voor in die sin:

Ek wou skree maar kon geen woord uit nie.

Waar ellips voorkom, is dit dikwels eerder die foutiewe weglating van elemente, byvoorbeeld:

Die meeste van hulle gebruik hierdie vuurwapens om ander mense dood te skiet en gebruik ook in diefstal.

Ten opsigte van konjunksie is gevind dat sommige tekste gekenmerk word deur 'n opvallende gebrek aan konjunksiemerkers sodat daar nie 'n logiese vloei tussen tekssinne ontstaan nie. In hierdie gedeelte word verbande nie tussen gedagtes in sinne gelê nie en 'n duidelike samehangende eenheid word nie gevorm nie.

In ander tekste is gevind dat baie van konjunksiemerkers gebruik gemaak is, maar die konjunksiemerkers wat gebruik is, het nie altyd 
sinvolle semantiese skakeling tussen proposisies tot gevolg nie, soos in die onderstaande sinne. In hierdie verband sê Carstens (1997:272):

As die produseerder die merker(s) so kies dat die aangesprokene nie die nodige mentale verbinding kan maak nie, sal die aangesprokene belang verloor en kan die bedoelde teks as kommunikasiegebeurtenis misluk.

Dit is veral temporele konjunksiemerkers wat hier ter sprake kom, byvoorbeeld:

Bylaag 3: Dan ek skrik my boeglam.

(Dan in 'n opeenvolgende verband wat verwys na 'n tydstip in die toekoms in plaas van toe wat verwys na 'n tydstip in die verlede.)

Bylaag 2: Wanneer ek by die Universiteit kom studeer het ek gedink om 'n verpleegster student te wees omdat ek hou baie van gesondheid.

(Wanneer, wat gewoonlik in 'n voorwaardelike verband gebruik word, is hier verkeerdelik gebruik in plaas van toe wat 'n bepaalde tydstip aandui.)

Behalwe vir die foutiewe keuse van konjunksiemerkers, is daar ook gevind dat die ondersoekte tekste meestal dui op 'n gebrek aan kennis by die teksproduseerders ten opsigte van aanvaarbare sinsvolgordes by saamgestelde sinne in Afrikaans. Dit is veral die volgorde van sowel neweskikkende as onderskikkende sinne met voegwoorde vooraan, wat foutief is. Dit bemoeilik die leesproses en benadeel die semantiese eenheid van die teks, byvoorbeeld:

Ek glo nie aan spoke nie, MAAR daardie nag ek glo DAT die spook was daar.

TOT vandag ek glo die spook was hier.

Daar is gevind dat leksikale kohesie die dominante bindingsketting in die ondersoekte tekste is en dat hierdie tipe kohesieskakel die meeste in die ondersoekte tekste voorkom. Verskillende tipes leksikale kohesie is aangetref, byvoorbeeld:

herhaling van woorde: spook x spook

sinonieme:

bang, angs, vrees; spook, iets bonatuurliks, 'n wit gedaante, gees, huis, opstal, spookhuis,

meronieme: huis, vensters, ruite,

geordende reekse: jaar, maand, dae 
As gevolg van die belangrike rol wat leksikale kohesie in die totstandkoming van tekste speel, kan hierdie komponent ondersteun word deur die onderrig daarvan. Daardeur kan byvoorbeeld aandag geskenk word aan sinonieme, antonieme, hiponieme, ensovoorts, in teorie wat aangevul word deur oefeninge. Wessels (1994:134) wys ook op die verwantskap wat daar bestaan tussen leksikale kohesie en koherensie in die akademiese skryfwerk van studente.

Alhoewel kohesie nie as 'n verpligte element ten opsigte van tekstualiteit gesien word nie, vervul dit 'n belangrike bindingsfunksie in die teks.

Ten opsigte van die beginsel koherensie is gevind dat in die ondersoekte tekste van T2-sprekers van Afrikaans, hierdie beginsel dikwels problematies is aangesien opeenvolgende sinne in 'n teks nie altyd logies bymekaar inskakel om ' $n$ sinvolle geheel te lewer nie. Vergelyk byvoorbeeld die onderstaande gedeelte uit 'n weergawe oor die verloop van die leerder se Paasvakansie:

Vir my eerste naweek het ek gedink aan my skoolwerkies. Hard soos dit was, het ek my planne voorkom. Selfs het ek nie genoeg tyd om saam met my vriende en familie te kan sit en gesels nie.

Waar het ek gekry. Dit was tyd dat ek kan my vriende en my gesinne besoek. Dagliks was ons besig om te prepareer vir die paasfees. Ons was by oom Mike se plek. Daar was ook 'n skou in Malvern skou gronde.

Paragraafindelings is dikwels onlogies en daar is soms nie aandag geskenk aan die belangrikheid van 'n deurlopende tema nie. Die tekseenheid word daardeur benadeel en die logiese vloei van die teks word versteur. Indien hierdie probleem dikwels voorkom, verloor die teksgebruiker belangstelling (byvoorbeeld by die skryf van 'n opstel of waar vrae wat oor spesifieke onderwerpe handel, soos geskiedenisvrae in opstelvorm beantwoord moet word) en die kommunikasie is nie geslaag nie.

\section{Die nut van 'n tekslinguistiese benadering}

Kennis aangaande die tekslinguistiek bied 'n gesistematiseerde raamwerk waarbinne nie net gebreke in T2-tekste op 'n geordende wyse blootgelê kan word nie, maar dit speel veral ook 'n belangrike rol by die skep van 'n sinvolle, logiese teks. (In hierdie opsig kan ook verwys word na skryfprosesteorieë om skryf te bevorder, maar in hierdie artikel word nie hierop verder ingegaan nie.) Logiese denke word ook bevorder deurdat eenheid in 'n teks beklemtoon word. Die beginsels koherensie en kohesie speel veral 'n belangrike rol. Koherensie beklemtoon same- 
hang en semantiese eenheid wat die teks meer verstaanbaar vir die ontvanger maak en dus lei tot suksesvolle kommunikasie. Kohesie beklemtoon nie alleen teksbinding nie, maar lewer 'n bydrae deurdat die korrekte woordgebruik in die oppervlakteks beklemtoon word, byvoorbeeld die korrekte gebruik van voornaamwoorde, konjunksiemerkers, ensovoorts. Die regulerende beginsels lewer veral 'n bydrae ten opsigte van die kwaliteit van die geproduseerde teks. Die rol van die teksdeelnemers ten opsigte van die geproduseerde teks word beklemtoon. Teoretiese kennis aangaande die tekslinguistiek vind dus 'n nuttige, sinvolle toepassing in die totstandkoming van geslaagde kommunikasie.

\section{Bibliografie}

Bamberg, B. 1984. Assessing coherence: a reanalysis of essays written for the national assessment of educational progress, 1969-1979. Research in the Teaching of English, 18(3):305-319.

Carstens, W.A.M. 1987. De Beaugrande en Dressler (1981) se 'standaarde van tekstualiteit'. Suid-Afrikaanse Tydskrif vir Taalkunde, 5(2):17-32.

Carstens, W.A.M. 1993. Die studieterrein van die tekslinguistiek. Suid-Afrikaanse Tydskrif vir Taalkunde, Supplement 15:1-14.

Carstens, W.A.M. 1997. Afrikaanse tekslinguistiek. 'n Inleiding. Pretoria : Van Schaik.

Carstens, W.A.M. 2000. Tekslinguistiek en teksversorging. Suid-Afrikaanse Tydskrif vir Taalkunde, Supplement 37:4-17.

Carstens, W.A.M. \& Van Schalkwyk, P.L. 1994. Standaarde van tekstualiteit en Breyten Breytenbach se "Die Boenk". Suid-Afrikaanse Tydskrif vir Taalkunde, Supplement 22:43-61.

De Beaugrande, R.A. \&. Dressler, W.U. 1981. Introduction to textlinguistics. London : Longman.

Donnelly, C. 1994. Linguistics for writers. Buffalo : SUNY Press.

Du Plessis, Hans. 2000. Teksheid: Die kreatiwiteitsgraad van 'n teks as aanduiding van die grense tussen taaldissiplines. Literator, 21(2):133-144.

Halliday, M.A.K. \& Hasan, R. 1976. Cohesion in English. London : Longman.

Hoey, M. 1991. Patterns of lexis in text. London : Oxford University Press.

Hubbard, E.H. 1989. Reference cohesion, conjunctive cohesion and relational coherence in student academic writing. Pretoria : Universiteit van Suid-Afrika. (D.Litt. et Phil.-proefskrif.)

Hubbard, E.H. 1993. Some coherence correlates in expository writing. SuidAfrikaanse Tydskrif vir Taalkunde, Supplement 15:55-74.

Hubbard, E.H. 1994. A process-orientated analysis of reference errors. SuidAfrikaanse Tydskrif vir Taalkunde, Supplement 22:63-79.

Kruger, A. 2000. Lexical cohesion and register variation in translation: The Merchant of Venice in Afrikaans. Pretoria : Universiteit van Suid-Afrika. (D.Litt. et Phil.proefskrif.)

Ponelis, F.A. 1979. Sintaksis. Pretoria : Van Schaik.

Pretorius, E.J. 1994. A text-linguistic perspective on causality in discourse: toward a taxonomy of causal relations. Suid-Afrikaanse Tydskrif vir Taalkunde, Supplement 22:81-122.

Prinsloo, S.M.C. 1994. Kohesiewerking in die spontane mondelinge vertelling in Afrikaans. Suid-Afrikaanse Tydskrif vir Taalkunde, Supplement 22:149-165. 
Prinsloo, S.M.C \& Seshoka, M.L. 2000. Verwysing binne 'n kontekstuele raamwerk. Suid-Afrikaanse Tydskrif vir Taalkunde, Supplement 37:90-107.

Van Schalkwyk, P.L. \& Carstens, W.A.M. 2000. Paradokse van koherensie. SuidAfrikaanse Tydskrif vir Taalkunde, Supplement 37:108-132.

Van Tonder, S.L. 2000. Lexical cohesion between an examination question prompt and its answers. Suid-Afrikaanse Tydskrif vir Taalkunde, Supplement 37:134148.

Wessels, E.M. 1994. Lexical cohesion and the teaching of academic skills. SuidAfrikaanse Tydskrif vir Taalkunde, Supplement 22:123-148.

\section{Kernbegrippe:}

diskoersanalise

onderrig van skryfvaardighede

T2-onderrig

tekslinguistiek

\section{Key concepts:}

discourse analysis

L2-teaching

teaching of writing skills

text linguistics

\section{Bylaag 1}

\section{Hoe ek my paasvakansie deurgebring het}

Die eerste tyd toe ons toe gesluit het by die Universiteit, het ek gedink hoe lekker is die paasvakansie. Ek het gedink van my skoolwerk wat ek het. Dit was heerlik swaar vir my om my toekomsplanne te kan voorkom.

Vir my eerste naweek het ek gedink van my skoolwerkies. Hard soos dit was, het ek my planne voorkom. Selfs het ek nie genoeg tyd om saam met my vriende en familie te kan sit en gesels.

Waar het ek gekry. Dit was tyd dat ek kan my vriende en my gesinne besoek. Dagliks was ons besig om te prepareer vir die paasfees. Ons was by oom Mike se plek. Daar was ook 'n skou 'n Malvern skou gronde.

Lekker soos dit was kan ek nie vergeet. Al die speletjies was daar vir kinders en groot mense. Hulle het alles daar verkoop, ou dinge, nuwe en allersoorte kos en dranks was daar. Alles van koopbar. Ek het 'n verjaarsdag persent vir my vriend gekop.

Vroeg was ons by die kerk. Die hele dag was ons by die kerk tot op ses uur toe ons by oom se plek gegaan. Al my vriende was daar. Allersoorte dranks en kos was daar. Ons het die hele nag gesing en dan tot 'n tyd 
waar elkeen van ons was moeg. Hierdie jaar se paasfees sal ek nooit vergeet want die hele gesinne en vriende was bymekaar.

\section{Bylaag 2}

\section{Waarom ek by die Universiteit van die Noorde kom studeer}

Wanneer ek by die Universiteit kom studeer het ek gedink om 'n verpleegster student te wees omdat ek hou baie van gesondheid. My plan was om 'n suster te wees om die siek kinders en volwassenes oppas. Ek het vorige jare by verskillende hospitaals die aansoek doen en hulle my antwoord sê dat al die spasie is vol. Dit is wanneer ek dink om by Universiteit kom studeer.

Die ander ding wat ek hierdie universiteit kis in plaas van die anders is dat ek het klein kinders wat ek moet oppas. Hulle is nog nie so groot om hulle-self kan bly.

Ek was baie teleursteld omdat die gesondheid spasie in die Universiteit van die Noorde was vol, ek was so deurmekaar omdat ek was nog nie gedink van ander studie. Daar was geen kans wat ek kan doen omdat ek lankal die registreer-geld betaal het, ek moet die ander ding kis. Later hoor ek van die vak "Media Studies" ek was beslis om dit te vat. Ek het later die vak baie geniet en hou van. Ek het na Mevrou Mabale toe gaan om te vra watter ander vakke moes ek kis, sy het eers gevra wat ek wil doen as my hoof vak, en ek sê Media en sy het my gewys watter eens te kis.

Hierdie jare, ek beplan om eendag 'n joernalis te wees, ek wil 'n geleerd persoon met mooi huisie, motor en 'n goeie werk hê en 'n goeie salaris kry om my kinders by die hoër skole toe stuur. Ek wil hulle geleerd word omdat hulle kan hulle kinders wel oppas. Ek wil my man help ensovoorts.

\section{Bylaag 3}

\section{'n Nagmerriegebeurtenis}

Ek het verlede jaar ' $n$ nagmerriegebeurtenis. Daardie dag het ek 'n spook gesin, want dit was 'n skaduwee soos 'n persoon nie 'n gewoonlike mens nie. lets met groot hande en 'n snaakse helder lig wat nie van die lamp gekom nie.

Ek was vas in die slaap toe ek iets hoor wat fluister saggies in my bed kamer, dan hoor ek 'n paar woorde sonder betekenis nie. Daar kom die skaduwee naby my bed en 'n snaakse lig, dan ek skrik my boeglam toe 
ek hom sien. Ek gaan onder die komberse in en begin skree. Die kamer was so stil dat niemand kan my help.

Die lig was so helder dat ek kon nie hom reg kyk nie. As ek luister na sy woorde, hy gryp my komberse af, ek was baie geskrik. Ek sien groot hande en lank vingers met vuur. Ek hoor my bed gaan kant tot kant. Ek was bang om op te staan ek skree hardop, hy hou my mond toe met sy groot hand met vuur.

Ek hoor hom saggies lag. Ek kon nie asemhaal nie, my keel was toe gemaak. Ek weet nie wat het gebeur met my, dan later ek was wakker my bene en hande was so styf. Ek kon nie praat nie, my stem was loos. Dan ek besef om op die bed gestaan. My beddegoed was nie meer op die bed nie maar op die vloer. Daar was nie meer die lig nie, alles was donker. Ek hoor my hart tik soos 'n horlosie. Ek het nie meer geslaap nie tot in die môre.

Dit was nie 'n restige slaap wat ek gehad nie. Ek het nie 'n groot hand soos daardie een gesien nie my kamer was verlig met 'n lig wat nie van die lamp gekom het nie, dit was 'n snaakse lig. Dit is hoekom ek sê dit is 'n nagmerriegebeurtenis. 
